\title{
Balance of sugarcane plantation land needs in Lamongan Regency in 2031 based on land-use changes using SPOT imagery
}

\author{
Salis Deris Artikanur ${ }^{\mathrm{a}}$, Widiatmaka $^{\mathrm{b}}$, Yudi Setiawan ${ }^{\mathrm{cd}}$, Marimin $^{\mathrm{e}}$ \\ ${ }^{a}$ Graduate School, IPB University, Kampus IPB Dramaga, Bogor, 16680, Indonesia [+62 85733085185] \\ ${ }^{\mathrm{b}}$ Department of Soil and Land Resources, Faculty of Agriculture, IPB University, Kampus IPB Dramaga Bogor, 16680, Indonesia \\ [+62 81314065828] \\ ${ }^{\mathrm{c}}$ Department of Forest Resource Conservation and Ecotourism, Faculty of Forestry and Environment, IPB University, Kampus IPB \\ Dramaga Bogor, 16680, Indonesia [+62 251-8621262] \\ ${ }^{\mathrm{d}}$ Center for Environment Research, Institution of Research and Community Empowerment, IPB University, Kampus IPB Dramaga \\ Bogor, 16680, Indonesia \\ ${ }^{e}$ Department of Agricultural Industrial Technology, Faculty of Agricultural Technology, IPB University, Kampus IPB Dramaga Bogor, \\ 16680, Indonesia [+62 81384125390]
}

\section{Article Info:}

Received: 24 - 05 - 2021

Accepted: $07-07-2021$

Keywords:

Development, planning, population, projection, selfsufficiency

Corresponding Author: Salis Deris Artikanur Graduate School, IPB University;

Tel. +6285733085185

Email:

sda.salis@apps.ipb.ac.id

\begin{abstract}
Nationally, sugar consumption ranges from 6 million tons per year, while the volume of Indonesia's sugar imports in 2019 reached 4.09 million tons. The land-use change dynamics strongly influenced national sugar production. Lamongan Regency is one of the sugarcane and sugar-producing regencies in East Java. Sugarcane and sugar production in Lamongan Regency has experienced quite diverse dynamics and has been influenced by changes in land-use conditions. This study aims to analyze the balance of land needs for sugarcane plantations in Lamongan Regency in 2031 based on an analysis of land-use changes using SPOT imagery of 2007, 2013, and 2019. The study was conducted by analyzing land-use changes, population projections, and land needs balance analysis for sugarcane plantations. The analysis results showed that the population of Lamongan Regency in 2031 is projected to reach 1419843 people, with a land requirement for sugarcane plantations of $2362.29 \mathrm{ha}$. There will be a land surplus of $1276.92 \mathrm{ha}$, but it is still concentrated in 7 of the 27 sub-districts. Sugarcane plantations in Lamongan Regency have the potential to be developed considering that the land allocation for plantations in the Lamongan Regency Spatial Plan of 2011-2031 reaches $10022.42 \mathrm{ha}$.
\end{abstract}

\section{How to cite (CSE Style $8^{\text {th }}$ Edition):}

Artikanur SD, Widiatmaka, Setiawan Y, Marimin. 2021. Balance of sugarcane plantation land needs in Lamongan Regency in 2031 based on land-use changes using SPOT imagery. JPSL 11(3): 397-407. http://dx.doi.org/10.29244/jpsl.11.3.397-407.

\section{INTRODUCTION}

National sugar consumption has experienced an upward trend of $6.14 \%$ from 2013 to 2016 (Kemendag, 2019). Meanwhile, per capita, sugar consumption grew by an average of $2.55 \%$ from 2013 to 2017 (BKP, 2017). Nationally, sugar consumption ranges from 6 million tons per year, while sugar production in Indonesia is only around 2.5 million tons. Indonesia needs to import 3 to 4.5 million tons of sugar per year to meet national sugar needs. In line with the increasing demand for national sugar, sugar imports have also experienced a similar trend. The volume of sugar imported into the country reached 4.09 million tons in 2019. Generally, sugar imported from various countries, such as Thailand (86.5\%), Australia (13.3\%), South Korea 
$(0.17 \%)$, and other countries $(0.03 \%)$ (BPS, 2020). Sugar imports may negatively impact the welfare of the local farmers, farming activities, and the sugar industry (Rahman et al., 2018). In addition, importing sugar in the long term can continue to reduce domestic production because prices at the farm level are low, and farmers lose their motivation to cultivate sugarcane. As a result, the trade balance continues to be negative, thereby threatening national food security (Safrida et al., 2020).

The trend of increasing demand and import of sugar is inversely proportional to the trend in sugar production. Sugar production has decreased as a result of the decreasing area of sugarcane plantations in Indonesia. In 2013, the area of sugarcane plantations in Indonesia was 470940 ha, then continued to decline from year to year. Until 2017, only 420150 ha of sugarcane plantations were left (BPS, 2018). Lamongan Regency is one of the regencies in East Java, Indonesia, that produces sugarcane. The sugar produced by Lamongan Regency was 25280 tons in 2019. East Java Province contributed 52.34\% or 1.15 million tons of the total national sugar production in 2017 (BPS, 2018). Sugarcane plantations in Lamongan positively impact the welfare of sugarcane farmer households (Anam and Qibtiyah, 2018). Smallholder plantations can be developed, thereby increasing community income in the area (Widiatmaka et al., 2013).

Sugarcane and sugar production in Lamongan Regency has experienced quite diverse dynamics and has been influenced by changes in land-use conditions, including sugarcane plantations. The distribution and area of land use in Lamongan Regency can be analyzed spatially and temporally to determine the balance of the needs for sugarcane plantations to meet sugar needs. However, sugar needs can change according to the increase or decrease in population. Population growth follows an exponential pattern, while available natural resources follow a linear pattern (Subair, 2015). This study, therefore, aims to analyze the balance of land needs for sugarcane plantations in Lamongan Regency in 2031 based on an analysis of land-use changes using SPOT imagery in 2007, 2013, and 2019. This research is expected to be an input to the local government of Lamongan Regency to develop sugarcane plantations so that sugar self-sufficiency can be achieved regionally and nationally.

\section{METHODS}

\section{Study Area}

This research was conducted in Lamongan Regency using the sub-district analysis unit where there are 27 sub-districts in Lamongan Regency. The study was conducted using the existing years of 2007, 2013, and 2019 and the projection year of 2031. The projection year of 2031 is the end year of the Spatial Plans (RTRW) for Lamongan Regency in 2011-2031; thus, it is expected to be an input in the preparation of the RTRW for the following year. The research study area is shown in Figure 1.

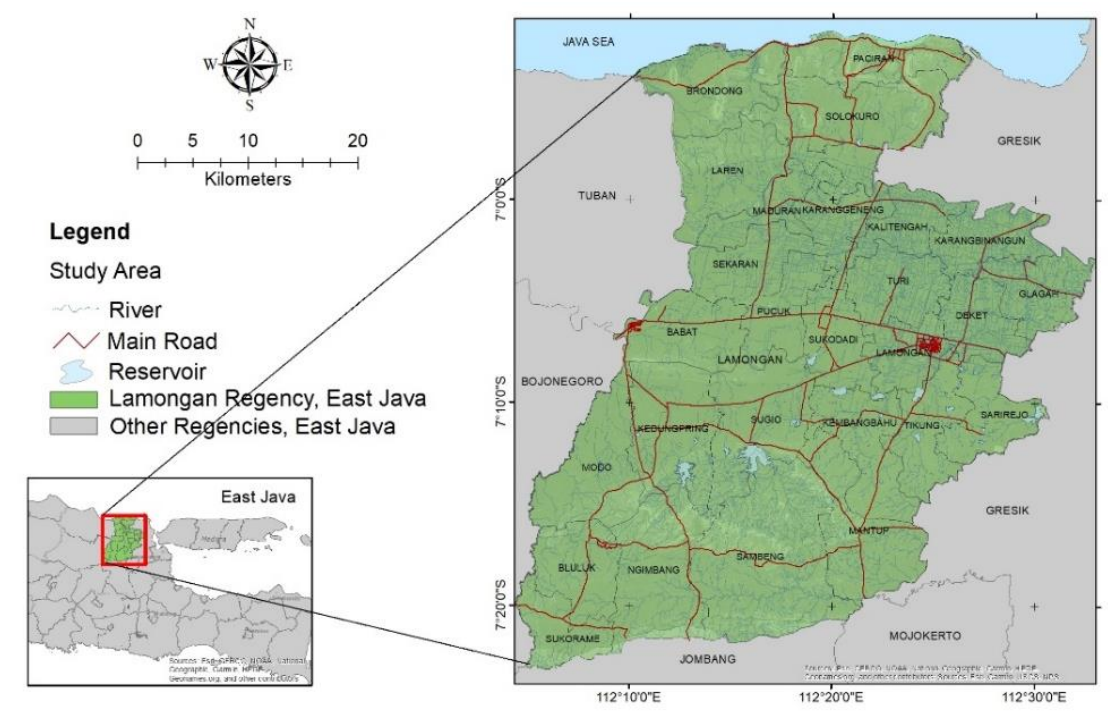

Figure 1 Research study area 


\section{Data Collection Method}

The data needed in this study consists of primary data and secondary data. The primary data used was in the form of field check coordinates to test the accuracy of the land-use analysis. Field check coordinates were collected using the purposive sampling method with a total sample of 72 points located in various locations where eight sample points represented each land use. Meanwhile, the secondary data used SPOT satellite imagery for 2007, 2013, and 2019 obtained from LAPAN; data on population, sugarcane productivity, and consumption of sugar per capita sourced from BPS; rice field map in 2019 from ATR/BPN; forest area map 1: 250000 from the Ministry of Environment and Forestry; topographic map scale 1: 25000 from BIG; and Spatial Plan (RTRW) 2011-2031 map of Lamongan Regency from BAPPEDA.

\section{Data Analysis Method}

\section{Land-use in Lamongan Regency in 2007, 2013, and 2019}

This study used visual interpretation to analyze changes in land use. The land-use analysis was carried out in three points in 2007, 2013, and 2019 using SPOT imagery from LAPAN. There were nine types of landuse analyzed, including forests, fields/moor, built land, open land, sugarcane plantations, rice fields, shrubs, and water bodies. The use of land in rice fields was obtained from the rice field data of the Ministry of ATR/BPN to minimize misinterpretation. The forest area map from the Ministry of Environment and Forestry was used as a reference for interpreting forest cover. After the image interpretation was obtained, the accuracy test was carried out using the Kappa Index, and the area of each type of land use was calculated in each subdistrict. The formula of Kappa Index is:

$$
\mathrm{K}_{i}=\frac{N \sum_{i=1}^{r} X_{i i}-\sum_{i=1}^{r}\left(X_{i+}+X_{+i}\right)}{N^{2}-\sum_{i=1}^{r}\left(X_{i+}+X_{+i}\right)} \ldots \ldots \ldots(\text { Foody, 2002) }
$$

where:

$\mathrm{Ki}=$ Kappa Index

Xii $=$ type-i of land use classification results that match the type-i of land use as a result of observation

$\mathrm{Xi}+=$ type-i of land use classification result

$\mathrm{X}+\mathrm{i}=$ type $-\mathrm{i}$ of land use as a result of observation

$\mathrm{N}=$ total of all observation points

$\mathrm{r} \quad=$ total types of land use

\section{Balance of Land Requirements for Sugarcane Plantation}

The balance of sugarcane demand in Lamongan Regency was calculated beforehand according to the population projection in 2031 to determine the amount of sugar demand based on the population for that year. Furthermore, the calculation of sugarcane needs could be carried out based on per capita sugar consumption and population data. The sugarcane plantation area from land-use classification was then used to calculate sugarcane production by multiplying productivity data.

\section{Population projection}

Calculation of population growth rate and population projection in the future used exponential estimates. Many institutions and studies have calculated population projections, including BPS (2010), Mekonnen (2018), and Al-Eideh and Al-Omar (2019). The formulas for calculating the population growth rate and population projection are:

where:

a. Population Growth Rate (r)

$$
r=\frac{1}{t} \ln \left(\frac{P_{t}}{P_{0}}\right) \ldots \ldots \ldots . .(\text { Biswas, } 1988)
$$


b. Population Projection

$$
P_{t}=P_{0} e^{r t} \ldots \ldots \ldots \ldots \text { (Biswas, 1988) }
$$

$\mathrm{P}_{\mathrm{t}}=$ total population in year-t (projection results)

$\mathrm{P}_{0}=$ total population in year 0 (base year)

$\mathrm{r}=$ population growth rate

$\mathrm{t}=$ the period between year- 0 and year- $\mathrm{t}$

$\mathrm{e}=$ the principal number of the natural logarithmic calculation system (2.7182818)

\section{Calculation of sugarcane needs}

The value of sugarcane needs was obtained by modifying the formula for calculating the food balance in the form of rice. The value of per capita sugar consumption used in this calculation is the value of per capita sugar consumption according to BKP (2017), which is $9.25 \mathrm{~kg} / \mathrm{capita} / \mathrm{year}$. The following is the formula for calculating sugarcane needs in Lamongan Regency:

$$
K p=\left(\frac{K_{g} * P_{t}}{n}\right) \ldots \ldots \ldots . .(\text { Murdaningsih } \text { et al., 2017) }
$$

where:

$\mathrm{Kp}=$ sugarcane needs (ton)

$\mathrm{Kg}$ = sugar consumption per capita is $9.25 \mathrm{~kg} /$ capita/year

$\mathrm{Pt}=$ total population in year-t (people)

$\mathrm{n} \quad=$ the conversion value from sugarcane to sugar (yield value of sugarcane) is 0.0795

\section{Calculation of sugarcane plantation land needs}

The need for sugarcane plantation land per sub-district is calculated by dividing the need for sugarcane per sub-district by the average sugarcane productivity in Lamongan district. The average sugarcane productivity in Lamongan Regency is 70.66 tons/ha. Based on this method, the area of sugarcane plantations can be known to meet the needs of sugarcane per sub-district so that it can be allocated in the planning of the development of sugarcane plantations in the future.

\section{Sugarcane plantation land balance in lamongan regency}

Sugarcane plantation land balance uses the concept of supply and demand. Supply comes from the value of existing sugarcane plantation land, while demand comes from the value of sugarcane plantation land needs. The supplied value in existing sugarcane plantation land was obtained through land-use classification using SPOT imagery. Meanwhile, the demand value in the form of sugarcane plantation land needs had been calculated in the previous stage. The formula for calculating sugarcane plantation land balance is:

where:

$$
S / D=P_{t}-K_{t} \ldots \ldots \ldots \text { (Rejekiningrum, 2013) }
$$

$\mathrm{S} / \mathrm{D}=$ surplus/deficit

$\mathrm{Pt}=$ existing sugarcane plantation land

$\mathrm{Kt}=$ sugarcane plantation land needs

If the calculation result is positive (+), there will be a land surplus. Meanwhile, if the calculation result is negative (-), there will be a land deficit. Therefore, the amount of sugarcane plantation land needed to meet the required shortage of sugarcane plantation land can be known. 


\section{RESULTS AND DISCUSSIONS}

\section{Land-use in Lamongan Regency in 2007, 2013, and 2019}

Sugarcane production in Lamongan Regency is primarily influenced by the area of sugarcane plantations which is closely related to other land-uses. Furthermore, land use changes over time. This study analyzed changes in land use in Lamongan Regency in 2007, 2013, and 2019 to determine the extent and distribution of land use consisting of forests, fields/moor, built land, open land, sugarcane plantations, rice fields, shrubs, and water bodies. The accuracy test showed that the Kappa Accuracy of land-use classification were 85.9\% (2019); $82.01 \%$ (2013); and $83.51 \%$ (2007). Based on the analysis, the types of land use that have increased from 2007 to 2019 include fields/moor, built land, open land, and sugarcane plantations. Meanwhile, land-uses that have decreased are forests, rice fields, shrubs, fishponds, and water bodies. The classification and area of each type of land-use in Lamongan Regency are presented in Figures 2 and Table 1.
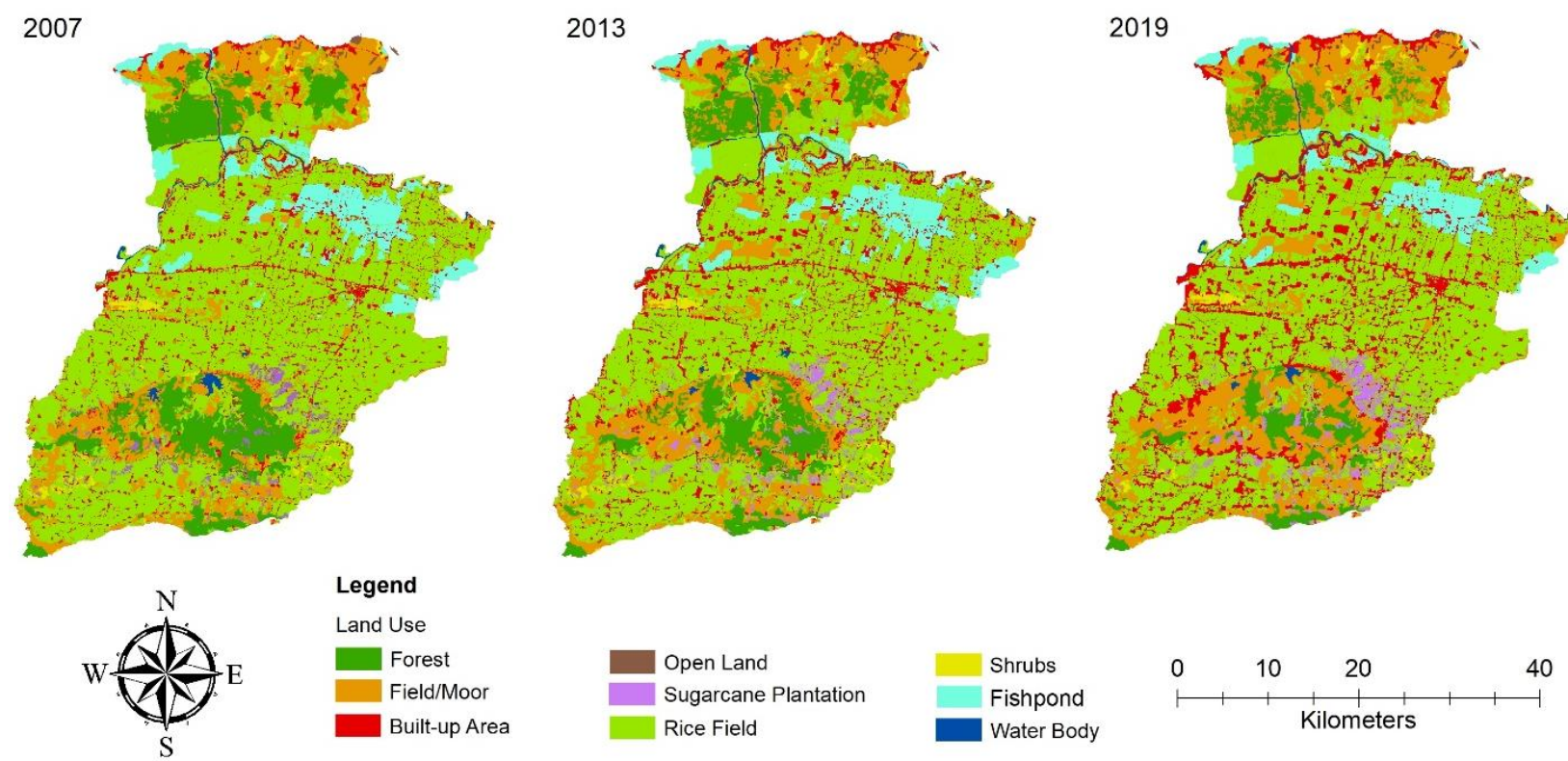

Figure 2 The results of land use classification in Lamongan Regency in 2007, 2013, and 2019

Table 1 The results of land use classification in Lamongan Regency in 2007, 2013, and 2019

\begin{tabular}{llrrrrrr}
\hline \multirow{2}{*}{ No } & Land-use & \multicolumn{2}{c}{2007} & \multicolumn{2}{c}{2013} & \multicolumn{2}{c}{2019} \\
\cline { 3 - 8 } & & \multicolumn{1}{c}{ Area } & $\begin{array}{c}\text { Percentage } \\
(\%)\end{array}$ & \multicolumn{1}{c}{$\begin{array}{c}\text { Area } \\
\text { (ha) }\end{array}$} & $\begin{array}{r}\text { Percentage } \\
(\%)\end{array}$ & $\begin{array}{c}\text { Area } \\
\text { (ha) }\end{array}$ & $\begin{array}{r}\text { Percentage } \\
(\%)\end{array}$ \\
\hline 1 & Forest & 19153.18 & 11.02 & 15627.90 & 8.99 & 10072.80 & 5.77 \\
2 & Fields/Moor & 24257.19 & 13.96 & 28358.89 & 16.32 & 32437.12 & 18.81 \\
3 & Built-up Area & 13517.98 & 7.78 & 17405.36 & 10.02 & 24298.18 & 13.80 \\
4 & Open Land & 310.18 & 0.18 & 316.88 & 0.18 & 333.98 & 0.22 \\
& Sugarcane & 2571.23 & 1.48 & 3476.26 & 2.00 & 4870.13 & 2.77 \\
& Plantation & & & & & & \\
6 & Rice Field & 98346.48 & 56.60 & 94419.02 & 54.34 & 89935.04 & 51.70 \\
7 & Shrubs & 2217.06 & 1.28 & 2168.70 & 1.25 & 1909.34 & 1.12 \\
8 & Fishpond & 12090.99 & 6.96 & 10840.00 & 6.24 & 8818.25 & 5.15 \\
9 & Water Body & 1301.80 & 0.75 & 1153.09 & 0.66 & 1091.26 & 0.66 \\
& Total & 175154.62 & 173766.10 & 100.00 & 173766.10 & 100.00 & 173766.10 \\
\hline
\end{tabular}


Sugarcane plantations in Lamongan Regency in 2007, 2013, and 2019 were 2575.93 ha; 3467.97 ha; and 4856.40 ha, respectively. The increase in sugarcane plantations in this period was influenced by the establishment of a sugar factory in 2015 in Lamongan Regency, which implemented partnerships with farmers to grow sugarcane. Sugarcane plantations in Lamongan Regency in 2007 were spread across 12 sub-districts including Babat, Bluluk, Kedungpring, Kembangbahu, Mantup, Modo, Ngimbang, Sambeng, Solokuro, Sugio, Sukorame, and Tikung. The largest sugarcane plantation was in Mantup Sub-District, which was 722.55 ha. Sugarcane plantations in 2013 in Lamongan Regency were spread across 14 sub-districts consisting of Babat, Bluluk, Kedungpring, Kembangbahu, Laren, Mantup, Modo, Ngimbang, Sambeng, Sarirejo, Solokuro, Sugio, Sukorame, and Tikung Districts with the largest area was in Mantup Sub-District which covered an area of 1 052 ha. Meanwhile, in 2019, sugarcane plantations in Lamongan Regency were only spread across 11 subdistricts, including Babat, Kedungpring, Kembangbahu, Laren, Mantup, Modo, Ngimbang, Sambeng, Solokuro, Sugio, and Tikung with the largest land area was in Mantup Sub-District which covered 1772.87 ha. Sugarcane-producing sub-districts in Lamongan in 2007, 2013, and 2019 are shown in Figure 3. The distribution and changes in the area of sugarcane plantations in Lamongan Regency in 2007, 2013, and 2019 are presented by a map in Figure 4.

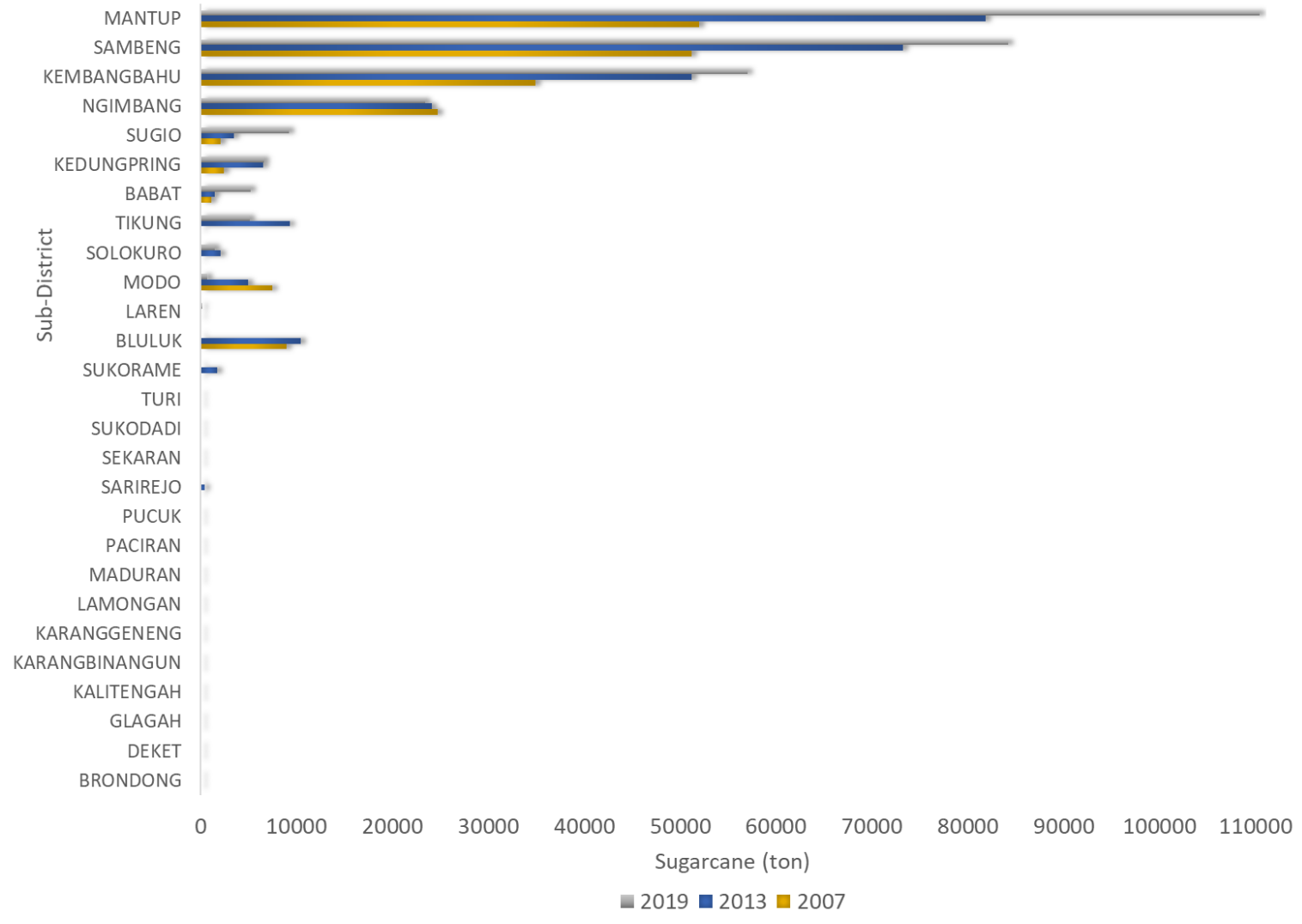

Figure 3 Sugarcane-producing sub-districts in Lamongan in 2007, 2013, and 2019

Based on Figure 4, it can be seen that there was an increase in the area of sugarcane plantations from 2007 to 2019. The increase in sugarcane plantation area from 2007 to 2019 generally came from forest land, fields/moor, and rice fields. The area of $94.89 \mathrm{ha}$, which was originally forest in 2007, was later converted into a sugarcane plantation in 2019. An area of 2.52 ha of fields/moor in 2007 was later converted into a sugarcane plantation in 2019. An area of 0.09 ha of open land was also converted into sugarcane plantations in 2019. Subsequently, there was a change in the function of the rice field of 2468.15 ha became sugarcane plantations from 2007 to 2019. Meanwhile, there was 2290.74 ha, which continued to function as a sugarcane plantation from 2007 to 2019. The matrix of land-use change from 2007, 2013, and 2019 in Lamongan Regency are shown in Table 2. 


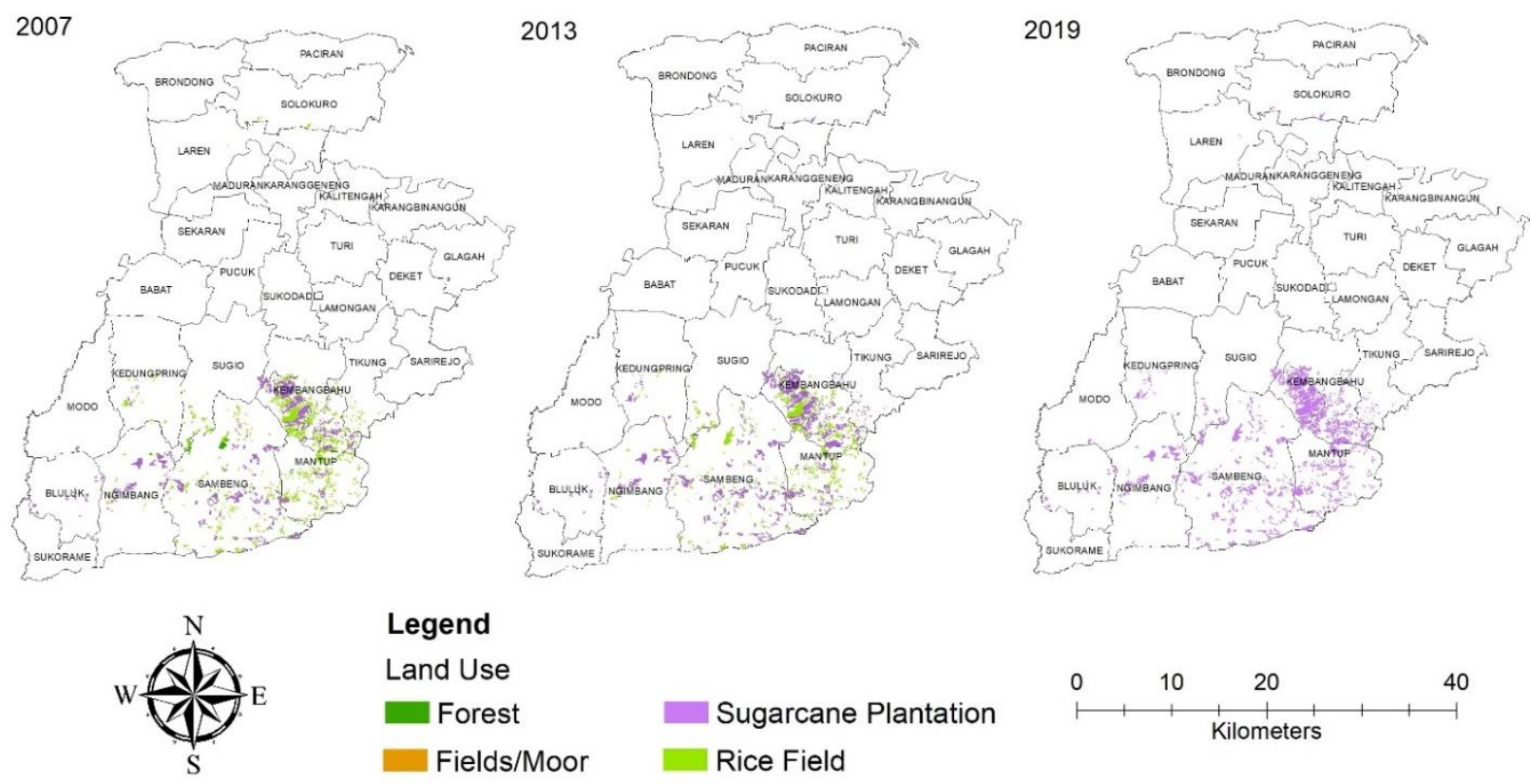

Figure 4 Distribution and changes in the area of sugarcane plantations in Lamongan Regency in 2007, 2013, and 2019

Table 2 Matrix of land-use change from 2007, 2013, and 2019 in Lamongan Regency

\begin{tabular}{|c|c|c|c|c|c|c|c|c|c|c|c|}
\hline & & \multicolumn{10}{|c|}{2019 Land-use } \\
\hline & & 1 & 2 & 3 & 4 & 5 & 6 & 7 & 8 & 9 & Total \\
\hline \multirow{10}{*}{$\begin{array}{c}2007 \\
\text { Land-use }\end{array}$} & 1 & 9704.02 & 8929.69 & 201.13 & 0.00 & 94.89 & 206.08 & 21.70 & 0.00 & 0.00 & 19157.51 \\
\hline & 2 & 271.15 & 21333.07 & 2508.99 & 43.53 & 2.52 & 78.15 & 0.00 & 9.44 & 10.87 & 24257.72 \\
\hline & 3 & 0.00 & 0.00 & 13513.66 & 0.00 & 0.00 & 0.00 & 0.00 & 0.00 & 0.00 & 13513.66 \\
\hline & 4 & 0.00 & 11.63 & 34.02 & 259.30 & 0.09 & 1.37 & 3.77 & 0.00 & 0.00 & 310.18 \\
\hline & 5 & 1.48 & 56.94 & 55.50 & 0.00 & 2305.92 & 145.66 & 5.72 & 0.00 & 0.00 & 2571.23 \\
\hline & 6 & 29.75 & 1876.35 & 7543.96 & 0.52 & 2466.70 & 86320.54 & 7.11 & 100.79 & 0.76 & 98346.48 \\
\hline & 7 & 66.40 & 0.14 & 274.77 & 0.00 & 0.00 & 4.24 & 1871.03 & 0.47 & 0.00 & 2217.06 \\
\hline & 8 & 0.00 & 1.82 & 165.60 & 30.62 & 0.00 & 3178.95 & 0.01 & 8707.26 & 6.72 & 12090.99 \\
\hline & 9 & 0.00 & 227.48 & 0.54 & 0.00 & 0.00 & 0.05 & 0.00 & 0.30 & 1072.90 & 1301.80 \\
\hline & Total & 10072.80 & 32437.12 & 24298.18 & 333.98 & 4870.13 & 89935.04 & 1909.34 & 8818.25 & 1091.26 & 173766.10 \\
\hline
\end{tabular}

Land-use type: 1 Forest, 2 fields/moor, 3 built-up area, 4 open land, 5 sugarcane plantation, 6 rice field, 7 shrubs, 8 fishpond, 9 water body

\section{Balance of Land Requirements for Sugarcane Plantation}

The existing conditions of the distribution of sugarcane plantations can be used to analyze the balance of land needs to meet the demand for sugarcane in Lamongan Regency. Calculation of the balance of land requirements for sugarcane plantations begins with an analysis of population growth. The positive impacts of population growth include the increasing variety of skills in society, increasing youth generation, motivation, and encouraging resource optimization (Khairul et al., 2018). Meanwhile, the negative impacts include degradation of environmental conditions, increased demand for resources, social conflicts, and increased unemployment (Jadhav and Ranveer, 2016). The population of Lamongan Regency increased from 1360987 people in 2017 to 1373390 in 2019 with a growth rate of 0.3\% per year. The projection results show that the population of Lamongan Regency in 2031 will be 1419843 people, with the largest population in Babat SubDistrict, namely 99201 people. 
As the population increases, the need for sugar cane to meet sugar needs also increases. The need for sugar in Lamongan Regency in 2031 is estimated to reach 13133.5 tons. When converted into sugarcane, the need for sugarcane to meet community needs is 165201.8 tons. In total, the average sugarcane production in 2007-2019 in Lamongan Regency reached 252895.4 tons; hence, there was a surplus of 87693.6 tons, but the areas that experienced a surplus were only scattered in 7 of the 27 sub-districts. The results of the projection of the population of Lamongan Regency in 2031 can be seen in Figure 5. While graphs population of Lamongan Regency in 2031 per sub-district can be seen in Figure 6. Sugarcane production, demand, and demand balance are presented in Figure 7.

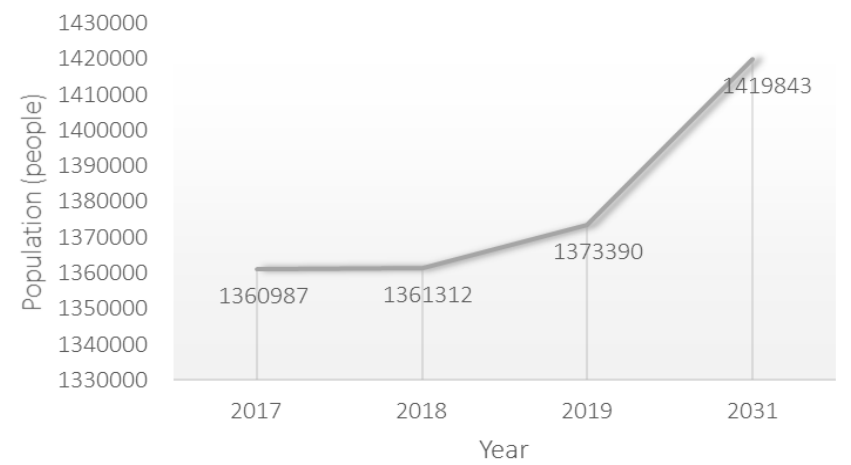

Figure 5 Total population of Lamongan Regency in 2007-2019

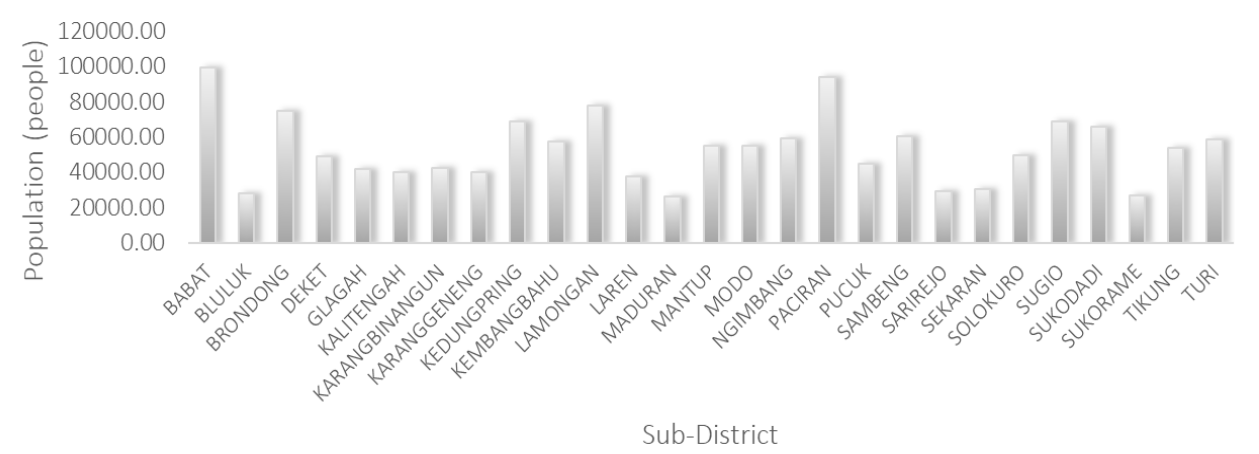

Figure 6 Population of Lamongan Regency in 2031 per sub-district

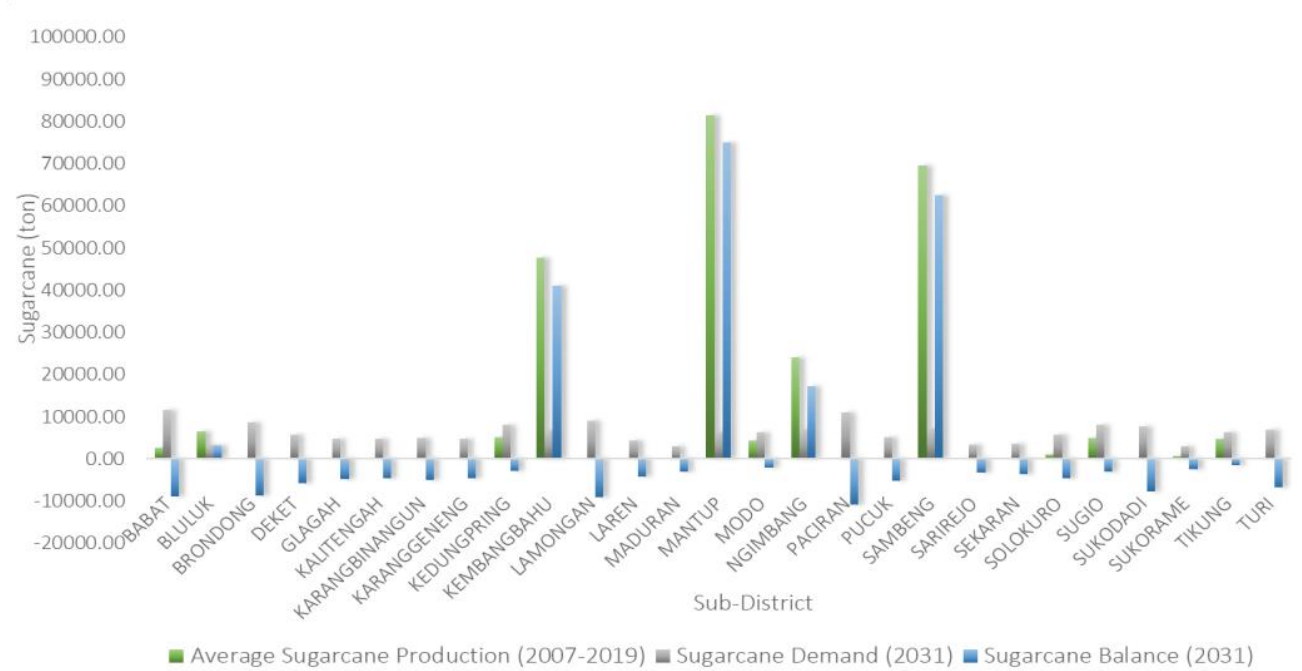

Figure 7 Average sugarcane production (2007-2019), sugarcane demand (2031), and sugarcane balance (2031) in 2031 Lamongan Regency 
The sub-district that experienced the largest surplus of sugarcane production was Mantup, which was 75 183.6 tons. The average sugarcane productivity in Lamongan Regency was 70.66 ton/ha; thus, based on the data, the total land required to meet sugarcane needs in Lamongan Regency is 2362.3 ha. The existing land area based on the results of land-use classification for sugarcane plantations in 2007, 2013, and 2019 were 2 575.93 ha, $3467.97 \mathrm{ha}$, and 4856.40 ha, respectively. This indicates that in total, the sugarcane plantation area currently available in Lamongan Regency has a surplus of 1276.92 ha. However, the distribution of surplus land is still concentrated in 7 of the 27 sub-districts. The seven sub-districts that will experience a surplus of sugarcane plantations include Bluluk, Kembangbahu, Mantup, Ngimbang, Sambeng, and Sugio. The average sugarcane plantations area (2007-2019), area needed for sugarcane plantations (2031), and sugarcane plantations land balance (2031) per sub-district is presented in Figure 8.

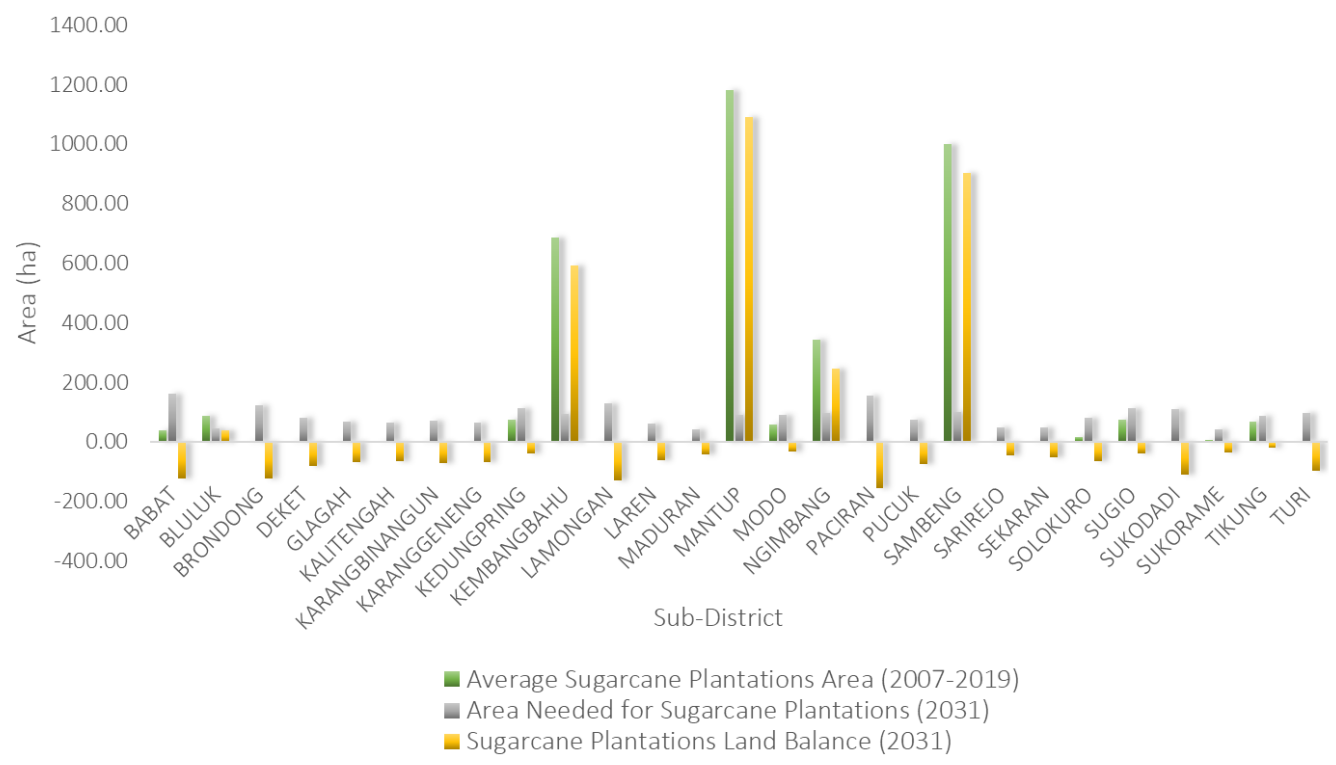

Figure 8 Average sugarcane plantations area (2007-2019), area needed for sugarcane plantations (2031), and sugarcane plantations land balance (2031) per sub-district

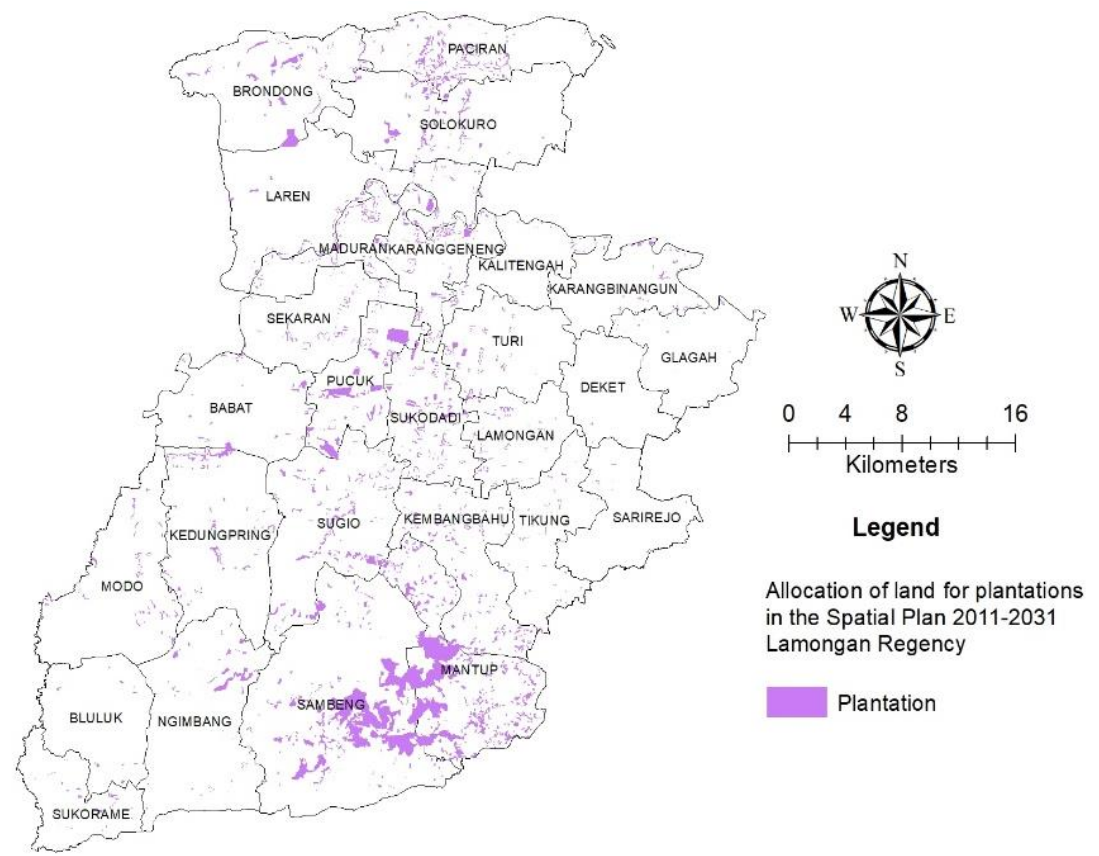

Figure 9 Land allocation for plantations in spatial plan 2011-2031 of Lamongan Regency 
Lamongan Regency, which has a total surplus of sugarcane plantations, still can be developed considering that the land allocation for plantations in the Spatial Plan 2011-2031 (RTRW) of Lamongan Regency reaches 10022.42 ha (Figure 9). Currently, there is no map of land suitability for sugarcane plantations in Lamongan Regency. The development of sugarcane plantations is supported by a sugarcane agroforestry program in collaboration between Perhutani and a sugar factory to revive Perhutani's idle land and improve community welfare. The importance of developing sugarcane plantations in Lamongan Regency is also based on establishing the largest sugar factory in Southeast Asia in 2016, which has a capacity of up to 12000 tons/day (Hanifiyah and Subari, 2020). Still, the production process is hampered due to the lack of available raw materials. The development of sugarcane plantations is expected to increase sugar production both regionally and nationally, thereby reducing sugar imports.

In addition to supporting the fulfillment of sugarcane and sugar needs both regionally and nationally, the development of sugarcane plantations also has the potential to improve community welfare. According to Anam and Qibtiyah (2018), sugarcane plantations in Lamongan are feasible to be cultivated based on the R-C ratio analysis. As many as $46 \%$ of sugarcane farmers who acted as respondents in Aminuddin's research (2016) argued that planting sugarcane was considered more profitable compared to previous cultivated crops. The existence of sugarcane plantations in Lamongan Regency also encourages the establishment of the People's Sugarcane Cooperative (KPTR), which can support the economic development of sugarcane farmers (Perdana and Nasution, 2016). The existence of KPTR makes it easy for sugarcane farmers to get capital, production facilities, carry out savings and loan activities, and improve coordination between sugarcane farmers.

\section{CONCLUSIONS}

Sugarcane plantation land in Lamongan Regency was experiencing dynamics caused by land-use changes. There was an increase in sugarcane plantations in Lamongan Regency from 2007 to 2019, amounting to 2 280.47 ha. Lamongan Regency experienced a sugarcane surplus of 87693.6 tons, as well as the area of sugar cane which reached 1276.92 ha. This surplus was only concentrated in 7 of the 27 sub-districts, so sugarcane plantations in Lamongan Regency are still quite vulnerable to changes in the future. Therefore, this provides an opportunity for the development of sugarcane plantations in other sub-districts. The development of sugarcane plantations is also supported by a program in the Spatial Plan (RTRW) of Lamongan Regency 20112031, the agroforestry program from Perhutani, and the establishment of a sugar factory. Sugarcane plantations in Lamongan Regency are expected not only to meet the needs of Lamongan Regency but also to contribute to national sugarcane and sugar production and improve the welfare of the population.

\section{ACKNOWLEDGEMENTS}

The authors acknowledge the Ministry of Research and Technology/National Research and Innovation Agency for the PMDSU research scheme Number: 200/SP2H/PMDSU/DRPM/2020, supervisors, lecturers, and staff of IPB University. We would like to thank IPB University, LAPAN, Ministry of ATR/BPN, Ministry of Environment and Forestry, Central Bureau of Statistics, Agency for Geospatial Information, Office of Food Crops, Horticulture, and Plantations of Lamongan Regency, and BAPPEDA Kabupaten Lamongan as the data source and research facilitator. The authors gratefully acknowledge all those who helped carry out this research.

\section{REFERENCES}

[BKP] Badan Ketahanan Pangan. 2017. Statistik Ketahanan Pangan 2017. Jakarta(ID): Badan Ketahanan Pangan.

[BPS] Badan Pusat Statistik. 2010. Pedoman Penghitungan Proyeksi Penduduk dan Angkatan Kerja. Jakarta(ID): Badan Pusat Statistik. 
[BPS] Badan Pusat Statistik. 2018. Statistik Tebu Indonesia 2017. Jakarta(ID): Badan Pusat Statistik.

[BPS] Badan Pusat Statistik. 2020. Statistik Indonesia 2020. Jakarta (ID): Badan Pusat Statistik.

[Kemendag] Kementerian Perdagangan. 2019. Analisis Perkembangan Harga Bahan Pangan Pokok di Pasar Domestik dan Internasional. Jakarta(ID): Kementerian Perdagangan.

Al-Eideh BM, Al-Omar HO. 2019. Population projection model using exponential growth function with a birth and death diffusion. Eur J Sci Res. 151(3): 271-276.

Aminuddin MI. 2016. Kajian perluasan lahan tanaman tebu terhadap berdirinya pabrik gula di Lamongan. Saintis. 8(2): 95-112.

Anam C, Qibtiyah M. 2018. Penelitian potensi perkebunan tebu terhadap kesejahteraan masyarakat Kabupaten Lamongan. Praja Lamongan. I(1): 46-54.

Biswas S. 1988. Stochastic Processes in Demography and Applications. Noida (IN): Wiley Eastern Limited.

Foody GM. 2002. Status of land cover classification accuracy assessment. Remote Sensing of Environment. 80: 185-201.

Hanifiyah M, Subari S. 2020. Eksternalitas pabrik gula PT. Kebun Tebu Mas Desa Lamongrejo Kecamatan Ngimbang Kabupaten Lamongan. Agriscience. 1(1): 324-338.

Jadhav PP, Ranveer A. 2016. Human population and environment: effects of population growth, climate changes and poverty relationship. Online Int Interdiscip Res J. 6: 54-60.

Khairul M, Kamarudin A, Wahab NA, Mohamad M, Shakir A, Saudi M. 2018. Population growth and economic development in developing and developed countries. Int J Eng Technol. 7(4): 123-127.

Mekonnen YA. 2018. Population forecasting for design of water supply system in Injibara Town, Amhara Region, Ethiopia. Civil and Environmental Research. 10(10): 54-65.

Murdaningsih, Widiatmaka, Munibah K, Ambarwulan W. 2017. Analisis spasial perubahan penggunaan lahan pertanian di Kabupaten Indramayu. Maj Ilm Globë. 19(2): 175-184.

Perdana Y, Nasution. 2016. Koperasi petani tebu rakyat Lamong Jaya. AVATARA. 4(1): 29-35.

Rahman ME, Sinaga BM, Harianto, Susilowati SH. 2018. Domestic support policies for neutralizing the negative impacts of import tariff reduction on Indonesian sugar industry. J Agro Ekon. 36(2): 91-112.

Rejekiningrum P. 2013. Model optimasi surplus beras untuk menentukan tingkat ketahanan pangan nasional. In: Prosiding Seminar Nasional Matematika, Sains, dan Teknologi. p 62-75.

Safrida, Sofyan, Taufani A. 2020. Dampak impor gula terhadap produksi tebu dan harga gula domestik di Indonesia. Agricore. 5(1): 35-48.

Subair. 2015. Relevansi teori malthus dalam diskursus kependudukan kontemporer. Dialektika. 9(2): 96-110.

Widiatmaka, Zulfikar, Anwar S, Ambarwulan W. 2013. Perencanaan spasial pemanfaatan lahan untuk komoditas perkebunan rakyat di Kabupaten Pidie Jaya, Provinsi Nangroe Aceh Darussalam. Geomatika. 19(1): 40-49. 